\title{
Under the wings of the Great Garuda: responsible port innovation in the Jakarta Bay area
}

\author{
B. A. Priyambodho ${ }^{1,2}$, C. Qin ${ }^{1,3} \&$ W. Ravesteijn $n^{1,3}$ \\ ${ }^{1}$ Delft University of Technology, The Netherlands \\ ${ }^{2}$ Sultan Ageng Tirtayasa University, Indonesia \\ ${ }^{3}$ Harbin Institute of Technology, China
}

\begin{abstract}
Port extension is economically important but difficult to implement in view of environmental and social objections, as port development projects are often contested innovations. Responsible Innovation (RI) addresses this issue by providing a motor for sustainable development, enhancing employment opportunities and incomes, while minimising detrimental social and environmental impacts. First and foremost, RI reconciles different interests and values, as these occur in the design and development process of any project. This paper illustrates how RI can be used to analyse conflicting values, and how it can contribute to reconciling these values in a project's design and development phases. We use the Jakarta Bay problems and plans, especially the Great Garuda Plan, as an example, focussing in particular on port expansion versus floodingrelated issues and solutions. On the one hand, flooding must be prevented for reasons of safety and sustainability, while on the other hand, Jakarta's Tanjung Priok port needs to be extended for the purpose of economic growth. The flooding occurs as a result of both the high and rising sea level and the huge discharges in the rivers flowing into the Jakarta Bay. We will focus especially on four dimensions of RI and on non-optimising design and development methods, which help engineers to deal with diverging values. We especially discuss Satisficing, the method of formulating thresholds for values and then selecting any option that at least meets these thresholds. In this paper, we create threshold values for safety (flooding), economics (port extension) and health and environment (air pollution) and apply these to alternative solutions. It is shown that RI will lead to better projects, especially in terms of societal and environmental values, and will thus
\end{abstract}


reduce public resistance to such projects, because all relevant stakeholder values such as safety and sustainability are taken into account during the innovation process.

Keywords: port cities, economic growth, subsidence, flooding, port extension, responsible innovation, conflicting values, satisficing.

\section{Introduction}

World port cities are crucial in connecting countries and islands, and thereby contribute substantially to economic growth. These cities currently face a number of conflicting challenges. On the one hand, they need to expand their infrastructure; on the other hand, they have to deal with pollution, urban expansion problems, climate change and an informed public. Economic growth and development are essential and the growing world economy allows developing countries to export commodities produced from within their rapidly expanding economies. Fundamentally, a country's economy and population develop in tandem with an increase in the number and size of ports and their infrastructures [1], although this results in a series of related issues that need to be resolved. Ports cities are essential to Indonesia, as the country consists entirely of islands, which for their development are dependent on their integration in the world economy. Indonesian ports were constructed and extended over a large number of years, and are now tackling the above-mentioned difficulties. One such site is Indonesia's main global port: Tanjung Priok. In their development, world port cities need to avoid complex and dramatic confrontations between negative values, such as water, air and noise pollution, and positive values such as economic ones. A rational process for resolving conflicting values is required and Responsible Research and Innovation provides this. First and foremost, RI is about involving all relevant actors and stakeholders, their interests and values, and reconciling these in development processes; we will demonstrate this here by focusing on the port of Jakarta. In the past decades, the Indonesian government resolved development problems in a non-structured, authoritarian manner, with little or no regard for environment and society. As a result, delicate environmental and social issues emerged and have become even worse, to the extent that the government is now forced to solve several problems at the same time. In the Jakarta Bay area, the government recently introduced the National Capital Integrated Coastal Development (NCICD) or Great Garuda Plan, in order to deal with all issues, including flooding and inadequate port space, mainly through closing off the Bay of Jakarta. This paper analyses the situation and this plan in terms of conflicting values incorporated in the two main problems of flooding in the city and extending the port, basically regarding matters of economics, safety and sustainability. We examine possible trade-offs and focus on non-optimal methods for dealing with conflicting values, especially Satisficing. We review the Great Garuda Plan, as well as the envisaged effects of the project if it is applied. Our questions here are: 
1. What is a Responsible Port Innovation?

2. Is Jakarta's Tanjung Priok port a good example, in terms of its operations and its plans for expansion?

3. How could Tanjung Priok improve its performance regarding its operations and its expansion plans, and become fully responsible?

4. What are the possibilities and limitations of Responsible Port Innovation in view of the Great Garuda Plan?

\section{Theoretical backgrounds: responsible (port) innovation}

\subsection{Responsible innovation}

Infrastructure projects in general are related to public interests and positive values in terms of economic benefits, and negative ones in terms of environmental and social issues during and after project construction. Consequently, new projects are difficult to undertake without the interests and values of all the stakeholders being taken into consideration. It is such situations that Responsible Research and Innovation (RRI or, shortly, RI) could be involved [2]. "Research and innovation must respond to the needs and ambitions of society, reflect its values, and be responsible... our duty as policy makers (is) to shape a governance framework that encourages responsible research and innovation" [3]. The concept of Responsible Innovation has been specified as four integrated dimensions. These dimensions strongly define the quality of social and environmental systems. The innovation performance is commonly found to be unacceptable or damaging; hence RI should be organised and monitored using regulatory instruments. "The dimensions are important characteristics of a more responsible vision of innovation" [4]. The four dimensions are anticipatory, reflective, responsive, and inclusive [2-5]. Anticipatory describes and analyses all kinds of things than can happen as an impact that might arise, such as economic, social, environmental or otherwise. There are a number of methods including Technology Foresight and Assessment that can be of help. Reflective involves researchers and innovators blurring the boundaries between their specific roles and responsibilities, considering institutional and other backgrounds. Responsive describes using this collective process of reflection with how to discuss, debate and conduct a dialogue, along with adapting the research and innovation process to integrate public values. Inclusive is "collective deliberation through processes of dialogue, engagement and debate, inviting and listening to wider perspectives from publics and diverse stakeholders" [3].

\subsection{Responsible port innovation}

Responsible Port Innovation (RPI) needs to incorporate several values, including safety, sustainability, economics, reputation, accessibility, and societal aspects [6]. In this paper, we focus on societal and economic values. The four dimensions of Responsible Innovation for port cities, requiring continuous commitment, are as follows: 
a. Anticipatory - Impact assessment studies are necessary. This dimension serves as a useful starting point for reflection upon the purpose, promises and possibilities for dealing with the impacts of innovation in port cities.

b. Reflective - External value systems and scientific practices have to be considered through mechanisms as codes of conduct, moratoriums and regulations. The European Sea Port Organisation (ESPO) provides standards and codes to facilitate and secure the green character and social integration of port innovations.

c. Responsive - Innovation should be carried out in reaction to social problems and on the basis of port values as well as stakeholder values.

d. Inclusive - All stakeholders potentially profiting or suffering from the initiatives should be included.

e. Dealing with conflicting values - Identifying and analysing value conflicts is crucial, as is the construction of balanced and justified trade-offs. Both optimal and non-optimal Methods are available for this [7].

\subsection{Dealing with conflicting values}

According to Van de Poel, "value is at the heart of engineering design". In dealing with conflicting values, he distinguishes optimal and non-optimal design methods [7]. The various approaches to optimal design include: a) efficiency and effectiveness as dominant values: both are usually needed when attempting to reach an optimal design and when evaluating different processes, for instance a port innovation struggling with the balance between time, cost and quality $[7,8]$; b) Cost-Benefit Analysis (CBA): all the effects of a project could be evaluated through giving them a monetary value; and c) Multiple-Criteria Analysis (MCA), a method that supports comparisons of policy options on the basis of several criteria assigned different weights [9]. Non-optimising approaches include: d) Satisficing, creating thresholds for each value and then nominating the alternatives that at least meet these thresholds; this method does not necessarily produce the best results, but ones that are 'good enough' from certain perspectives [7]; e) reasoning about values: this method does not measure and calculate, but gives priority to logical reasoning and judgment about values; f) value-sensitive design: the aim is to integrate values through conceptual, empirical and technical investigations [10]; and g) diversity, genre and holism. This method shows a range of different pictures through a number of possible justifications. The idea of genrebased evaluation looks more difficult to defend with an appreciation of moral values than with an appreciation of cultural or aesthetic values [7].

\subsection{Evaluation frame of responsible port innovation}

In this subsection, we develop characteristics of RPI according to the abovementioned theoretical perspectives. We specify the four dimensions and the dealing with conflicting values and we show how to apply these to ports' operational activities and plans for the future. The evaluation frame (see Table 1) of RPI provides the answer to question 1. 
Table 1: Evaluation frame of responsible port innovation $[2-5,7]$.

\begin{tabular}{|c|c|c|c|}
\hline & Item & Questions & Method to be used in RI \\
\hline 1 & Inclusive & Are all stakeholders involved? & $\begin{array}{l}\text { Stakeholder analysis, identifying } \\
\text { who, problems and values }\end{array}$ \\
\hline 2 & Responsive & $\begin{array}{l}\text { Are the problems of the stakeholders } \\
\text { being addressed? Are their values, } \\
\text { like safety, sustainability, liveability, } \\
\text { economic value, efficiency, being } \\
\text { served? }\end{array}$ & $\begin{array}{l}\text { Stakeholder analysis in view of the } \\
\text { proposed solutions }\end{array}$ \\
\hline 3 & Anticipatory & $\begin{array}{l}\text { Are all impacts considered and } \\
\text { prevented or repaired? }\end{array}$ & $\begin{array}{l}\text { Impact assessment, especially } \\
\text { environmental (EIA), social (SIA), } \\
\text { risk, safety, security (RA), } \\
\text { economic benefits }\end{array}$ \\
\hline 4 & Reflective & $\begin{array}{l}\text { Are relevant social and scientific } \\
\text { backgrounds considered? }\end{array}$ & $\begin{array}{l}\text { Are the ESPO criteria being met? } \\
\text { (Both from Societal Code \& Green } \\
\text { Guide) } \\
\text { - Public support and image } \\
\text { - Education and labour market } \\
\text { - Port-city relationships } \\
\text { - Environmental priorities }\end{array}$ \\
\hline 5 & $\begin{array}{l}\text { Dealing with } \\
\text { conflicting } \\
\text { values }\end{array}$ & $\begin{array}{l}\text { Are value conflicts being identified? } \\
\text { Are balanced trade-offs being made? }\end{array}$ & $\begin{array}{l}\text { 1. Optimal design: } \\
\text { - Cost-Benefit Analysis (CBA) } \\
\text { - Efficiency and effectiveness } \\
\text { - Multi-Criteria Analysis (MCA) } \\
\text { 2. Non-optimal design: } \\
\text { - Satisficing } \\
\text { - Reasoning about values } \\
\text { - Value-Sensitive Design (VSD) } \\
\text { - Diversity, genre, and holism }\end{array}$ \\
\hline
\end{tabular}

\section{Jakarta Bay area}

\subsection{Description}

Indonesia is currently ranked as the world's fourth most populous country [11], which has contributed to its continuing economic growth in recent years. Along with this growth, Indonesia has achieved the largest GDP in Southeast Asia [12], thus making it very attractive to manufacturers and investors, and increasing both demand and opportunities regarding the Tanjung Priok port. However, the nation's capital, Jakarta, is facing a number of problems, which - according to the Great Garuda Plan [13] - include flooding, solid waste, the catchment area, water supply, water quality, traffic, subsidence, and spatial planning. Therefore, the Great Garuda Plan for Jakarta's port must constitute part of an integrated solution. The most important social issue is flooding, because the protection level in the city's seaside zone is not sufficiently high. For this reason, Indonesia and the Netherlands worked together to create the 2011 Jakarta Coastal Defence Strategy (JCDS) [13].

\subsection{Port of Jakarta: present and future plans}

Jakarta's Tanjung Priok port was constructed between 1877 and 1885, with a brand new deep-water port for Batavia - the name for Jakarta in colonial times. 
However, the first concept of a maritime network was developed in the Dutch East Indies in 1980, and continued with an analysis of the economic and political development of the area. At this moment, the Indonesian Port Corporation (IPC) is the operator of the Tanjung Priok port and Otoritas Pelabuhan (OP) is the port authority. The port authority is a representative of the state government via the transportation ministry. Several port values can be distinguished, such as efficiency, economic, safety and sustainability. At the beginning of the $20^{\text {th }}$ century, the port of Jakarta was developed further in terms of management and policy [14]. Pelindo II is the name of the division of the IPC corporation directly responsible for the port, which currently employs over 18,000 people [15] and serves as Indonesia's main port, handling more than half of the country's containerised imports and exports $[16,17]$. Current studies of the Jakarta port, in relation to its role as part of the capital city, have noted several pressing issues, as a result of which the Indonesian government decided to invest in the expansion of the port in 2012, because of the expected economic benefits. This expansion aims to increase the port's total container handling capacity from its current 5 million to 18 million twenty-foot equivalent units per year (TEU) $[15,16]$.

\subsection{Great Garuda Plan}

The Great Garuda Plan for the coastal development of the national capital of Jakarta has, as its main purpose, the city's permanent protection against flooding from the sea. The limited catchment area resulting from urbanisation, heavy rain in the city and river floods are outside the scope of this Master Plan, though the subsidence (sinking) of the land caused by groundwater extraction worsens both types of flooding [13]. Implementation of the Master Plan consists of three main phases. Phase A involves strengthening the current sea wall and river dikes, referred to as "on-shore". Phase B consists of closing the western part of the bay with an outer sea wall, referred to as "off-shore". Phase C involves closing off the eastern part of the bay, which will only be necessary in the event that efforts to slow down or stop subsidence are unsuccessful in the area. The people in Jakarta need water for their daily activities, and the large retention lake created by the western dike (phases A and B) would provide fresh water, via a piped water supply, in order to reduce groundwater extractions and subsidence. However, the Great Garuda Plan does not only involve water management; it also integrates flood solutions with urban development, while at the same time generating revenues to finance flood protection measures. Also the port has to contribute to financing the flood protection. However, if the port authorities are unable to reduce the noise, air, and water pollution in Jakarta's Tanjung Priok port, they might not be able to help generate maximum revenue. The Great Garuda Plan will contribute significantly to the Tanjung Priok port by easing traffic congestion, and thereby boosting port activities. The Tangerang-Bekasi highway bridge will be designed to connect both ends of the Jakarta Bay with a 70-metre clearance to provide open access to the port. In this regard, more attention to details will be necessary, such as the times of high and low tide and the maximum height of shipping vessels, with a view to what could happen if circumstances would bring high tide, heavy rainfall and a tall ship together simultaneously. Subsidence in the eastern part of 
the coastal zone is lower, but a problem will arise if the $\mathrm{C}$ dike is built in the eastern area, as it might then be difficult for cargo ships to enter and leave Tanjung Priok during and following the dike's construction.

\section{Discussion}

\subsection{Analysis: evaluation of Jakarta's Tanjung Priok port plans}

Currently, the container traffic in the Tanjung Priok port is around 7 million TEU per year. The container traffic forecast for Tanjung Priok, by 2030, is 18 million, with an annual growth rate of $7.4 \%$ for the period 2008-2030. Port extension plans are already underway for the period up until 2030, and additional port expansions are foreseen after 2030. Under the Great Garuda Plan, the port can be further developed and integrated into an offshore dike. However, the development will be constrained in a number of ways if the bridge and/or the offshore dike in phase $\mathrm{C}$ were to be built. A closer examination is needed to determine the effects of a bridge and/or a dike, especially during low or high tides. Another limitation involves the water and air pollution associated with the port, since it would influence the value of surrounding real estate, causing land prices to be lower than expected. In this section, we evaluate Jakarta's Tanjung Priok port (see Table 2) in terms of operation and planning, before and after 2030, with regard to the evaluation frame that was explained in the theory section. Before 2030, the Great Garuda Plan has limited impact. After 2030, however, the port is fully part of the planning.

\subsubsection{Port expansion before 2030 [13]}

The outcomes of Great Garuda Plans prior to 2030 are more transparent than those to be implemented after 2030. In this section we briefly describe and explain what the Great Garuda Plan will mean. There are issues relating to:

a. Flood safety: dike(s) in phases A and B, creating the offshore retention basin and preparing the world's largest pumping stations, with a capacity of $730 \mathrm{~m}^{3} / \mathrm{s}$.

b. Social aspects: employment during and after construction, fisheries and fishing communities.

c. Land reclamation.

d. Business and residential properties.

e. Main port extension plans are already launched up until 2030.

The bridge of the Tangerang-Bekasi highway, as specified in the Master Plan, will have a 70 metres clearance to provide open sea access to the port Airport development.

f. Mobility and infrastructure.

g. Water management: polder management, rivers, retention reservoir.

h. Recreation and green-space.

i. Mitigation of negative environmental impacts. 
Table 2: Responsible port innovation: Jakarta's Tanjung Priok port $[13,18,19]$.

\begin{tabular}{|c|c|c|c|c|c|}
\hline & Item & $\begin{array}{l}\text { Performance until } \\
\text { now }\end{array}$ & $\begin{array}{l}\text { Port expansion } \\
\text { plans till } 2030\end{array}$ & $\begin{array}{l}\text { Port expansion } \\
\text { plans after } 2030\end{array}$ & Evaluation \\
\hline 1 & Inclusive & $\begin{array}{l}\text { Government agencies } \\
\text { (Ministry of } \\
\text { Transportation, Ministry } \\
\text { of BUMN, Special } \\
\text { Capital Region of } \\
\text { Jakarta) }\end{array}$ & $\begin{array}{l}\text { Government agencies } \\
\text { (Ministry of Public } \\
\text { Works, Bappenas, } \\
\text { Special Capital Region } \\
\text { of Jakarta), Coordinating } \\
\text { Ministry for Economic } \\
\text { Affairs } \\
\end{array}$ & N/A & $\begin{array}{l}\text { No stakeholder } \\
\text { analysis }\end{array}$ \\
\hline 2 & Responsive & $\begin{array}{l}\text { 1.Flooding no issue } \\
\text { 2.Tanjung Priok port has } \\
\text { no space to expand and } \\
\text { can only accommodate } \\
\text { limited sized ships }\end{array}$ & $\begin{array}{l}\text { 1. The bridge of the } \\
\text { Tangerang-Bekasi } \\
\text { highway with a } \\
\text { clearance of } 70 \mathrm{~m} \text { in } \\
\text { eastern part of Jakarta } \\
\text { Bay area } \\
\text { 2.Port extension plans } \\
\text { are already launched } \\
\text { until } 2030\end{array}$ & $\begin{array}{l}\text { 1. Building C dike is } \\
\text { anticipated in case } \\
\text { subsidence in eastern } \\
\text { Jakarta cannot be } \\
\text { stopped } \\
\text { 2.Ports extensions up } \\
\text { to } 2050 \text { are included } \\
\text { in the phase C design }\end{array}$ & $\begin{array}{l}\text { Port identified } \\
\text { values, but did } \\
\text { not do an } \\
\text { analysis or } \\
\text { resolve value } \\
\text { conflicts }\end{array}$ \\
\hline 3 & Anticipatory & N/A & $\begin{array}{l}\text { 1.Fishery activities and } \\
\text { aquaculture in Jakarta } \\
\text { Bay } \\
\text { 2.Economic functions } \\
\text { along the coast } \\
\text { 3.Environmental and } \\
\text { coastal marine habitat }\end{array}$ & $\begin{array}{l}\text { 1.Environment } \\
\text { 2.Safety }\end{array}$ & $\begin{array}{l}\text { Port does not } \\
\text { fully meet this } \\
\text { dimension }\end{array}$ \\
\hline 4 & Reflective & N/A ESPO criteria & $\begin{array}{l}\text { 1.Air quality } \\
\text { management } \\
\text { 2.Noise management } \\
\text { 3.Waste management } \\
\text { 4.Water (both } \\
\text { consumption and } \\
\text { quantity) management }\end{array}$ & $\begin{array}{l}\text { 1.Air quality } \\
\text { management } \\
\text { 2.Noise management } \\
\text { 3. Waste management } \\
\text { 4. Water (both } \\
\text { consumption and } \\
\text { quantity) } \\
\text { management }\end{array}$ & $\begin{array}{l}\text { Master plan } \\
\text { does not } \\
\text { include } \\
\text { societal } \\
\text { integration } \\
\text { from ESPO } \\
\text { criteria }\end{array}$ \\
\hline 5 & $\begin{array}{l}\text { Dealing with } \\
\text { conflicting } \\
\text { values }\end{array}$ & $\begin{array}{l}\text { 1.Optimal design: } \\
\text {-CBA } \\
\text {-MCA } \\
\text {-Efficiency } \\
\text { 2.Non-optimal design: } \\
\text { N/A }\end{array}$ & $\begin{array}{l}\text { 1.CBA } \\
\text { 2.Non-optimal design: } \\
\text { N/A }\end{array}$ & $\begin{array}{l}\text { 1.CBA } \\
\text { 2.Non-optimal } \\
\text { design: N/A }\end{array}$ & $\begin{array}{l}\text { Non-optimal } \\
\text { design was not } \\
\text { used for all } \\
\text { phases }\end{array}$ \\
\hline
\end{tabular}

\subsubsection{Port expansion after 2030}

The Great Garuda Plan contains very little information regarding the Master Plan after 2030. However, mentioned are: extension of phase A to provide safety, development of land reclamations and an outer sea wall or dike.

According to the Evaluation Frame of Responsible Port Innovation (see Tables 1 and 2), Jakarta's Tanjung Priok port is not entirely on the right track. In other words, it does not fulfil the requirements of Responsible Innovation. For this reason, in the next section we make several recommendations for improvement in terms of operational activities and expansion plans.

\subsection{Recommendations for Jakarta's Tanjung Priok port}

\subsubsection{General recommendations}

Our analysis of the Tanjung Priok port operations and plans and the impact of the Great Garuda Plan gives rise to a number of recommendations (see Table 3). 
Table 3: Recommendation for the Jakarta's Tanjung Priok port $[19,20]$.

\begin{tabular}{|l|l|l|}
\hline & Item & Recommendations \\
\hline 1 & Inclusive & $\begin{array}{l}\text { Fishermen, Parliament and NGOs should also be considered to create dialogue } \\
\text { concerning values of stakeholders }\end{array}$ \\
\hline 2 & Responsive & The problems of fishing communities are not sufficiently considered \\
\hline 3 & Anticipatory & $\begin{array}{l}\text { Apply Impact Assessment: environmental (EIA), social (SIA), risks (RA), and economic } \\
\text { costs in the Great Garuda Plan after 2030 }\end{array}$ \\
\hline 4 & Reflective & $\begin{array}{l}\text { Apply the societal integration ESPO criteria in the Master Plan: } \\
\text { a. General public support and image } \\
\text { b. Education, labour market and (future) employees } \\
\text { c. Port-city relationships around port areas, co-operation between cities and ports }\end{array}$ \\
\hline 5 & $\begin{array}{l}\text { Dealing with } \\
\text { conflicting } \\
\text { values }\end{array}$ & $\begin{array}{l}\text { a. Analyse and identify value conflicts between health, environment, safety and } \\
\text { economics } \\
\text { b. Apply non-optimising methods for the plans until 2030 and after 2030, esp. } \\
\text { Satisficing. Section 4.2.2 explains how the satisficing method can be used }\end{array}$ \\
\hline
\end{tabular}

\subsubsection{Satisficing}

Jakarta's Tanjung Priok port involves a number of values, including efficiency, economics, safety and sustainability. Satisficing is one method of dealing with conflicting values, by "setting thresholds for each value and then selecting any option that exceeds those thresholds. Setting threshold values not only occurs in the design process but also in legislation and the formulation of technical codes and standards" [7]. These codes enable several values to be combined. In our case, the Tanjung Priok port is a "static context", which means that "all the options are known with a certain probability and the options are readily available" [8]. We believe that the Great Garuda Plan will increase significant tensions between relevant values, and hence we use a trade-off analysis between safety and health values (flooding and pollution) and economic values (port extension). Trade-offs are necessary when choices have to be made between several alternatives, resolving these conflicts. Our scoring table ranges from double minus (- -) to double plus $(++)$, which we specify as follows:

$++=$ desirable at the highest level (the best option);

$+=$ acceptable, good enough;

- = unacceptable

- - = rejectable, the lowest level.

Trade-offs situations often occur when dealing with safety values and environmental values, when thresholds have to be balanced against each other. With the Satisficing method, trade-off possibilities between threshold values, before and after 2030, can be assessed as acceptable, desirable and unacceptable. We have threshold values for health and environment (air pollution), safety (flood), and economics (port extension). Several alternatives as to the construction of bridge and dike are distinguished. Finally, we assign scores, enabling us to draw conclusions (see Table 4).

The final results are:

$++=$ desirable, the alternatives $\mathrm{G}$ and $\mathrm{H}$;

$+=$ acceptable, the alternatives $\mathrm{C}, \mathrm{D}$ and $\mathrm{F}$;

- = unacceptable, the alternatives A, B and E. 
Table 4: Threshold values applied to Jakarta's Tanjung Priok port plans (before and after 2030).

\begin{tabular}{|c|c|c|c|c|c|}
\hline Alternative & Criteria & $\begin{array}{c}\text { Traffic (health and } \\
\text { environment/air } \\
\text { pollution) }\end{array}$ & $\begin{array}{l}\text { Safety } \\
\text { (flood) }\end{array}$ & $\begin{array}{l}\text { Economic (port } \\
\text { extension) }\end{array}$ & $\begin{array}{l}\text { Total } \\
\text { Score }\end{array}$ \\
\hline \multicolumn{6}{|c|}{ Values (before 2030) } \\
\hline A & $\begin{array}{l}\text { 1. No bridge } \\
\text { 2. No dike }\end{array}$ & - & - - & ++ & - \\
\hline B & $\begin{array}{l}\text { 1. Bridge } \\
\text { 2. No dike }\end{array}$ & + & - - & + & - \\
\hline $\mathrm{C}$ & $\begin{array}{l}\text { 1. High bridge } \\
\text { (more than } 70 \mathrm{~m}) \\
\text { 2. No dike }\end{array}$ & + & -- & ++ & + \\
\hline $\mathrm{D}$ & $\begin{array}{l}\text { 1. Hydraulic bridge } \\
\text { 2. No dike }\end{array}$ & + & -- & ++ & + \\
\hline \multicolumn{6}{|c|}{ Values (after 2030) } \\
\hline $\mathrm{E}$ & $\begin{array}{l}\text { 1. No bridge } \\
\text { 2. Dike }\end{array}$ & - & ++ & - & - \\
\hline $\mathrm{F}$ & $\begin{array}{l}\text { 1. Bridge } \\
\text { 2. Dike }\end{array}$ & + & ++ & -- & + \\
\hline G & $\begin{array}{l}\text { 1. High bridge } \\
(\text { more than } 70 \mathrm{~m}) \\
\text { 2. Dike }\end{array}$ & + & ++ & - & ++ \\
\hline $\mathrm{H}$ & $\begin{array}{l}\text { 1. Hydraulic bridge } \\
\text { 2. Dike }\end{array}$ & + & ++ & - & ++ \\
\hline
\end{tabular}

Satisficing does not produce the best option, but options should be good enough or "acceptable", hence we conclude that alternatives C, D and F are the outcomes of the Satisficing method. In the alternatives $\mathrm{C}$ and $\mathrm{D}$, the economic and health/environmental values are respected, while before 2030 a flooding level of 2.5 meters is considered acceptable. People can go to the roof and/or a second floor. However, after 2030 the Great Garuda, as an iconic and business city, does not allow or permit flooding anymore. The most important challenges of alternatives $\mathrm{C}$ and $\mathrm{D}$ are how to design a bridge higher than 70 meters and how to incorporate a hydraulic bridge into the eastern part of Jakarta Bay.

\section{Conclusion}

\subsection{Summary}

We can summarise the answers to our questions as follows:

1. The concept of Responsible Port Innovation (RPI) consists of four dimensions, i.e. anticipatory, reflective, responsive and inclusive, as well as methods to create balanced trade-offs, as explained in sections 2.4 and 2.5.We used these concepts in our case study of Jakarta's Tanjung Priok port in relation to the Great Garuda Plan.

2. As argued in section 4.1, the Tanjung Priok port failed to meet the RPI criteria. Hence, we can say that the port is not a good example of Responsible Port Innovation, both in its operations and its plans for expansion. 
3. The Tanjung Priok port can improve its performance regarding operations and its extension plans, and become fully responsible by using our recommendations, as described in sections 4.2 and 5.2 and below.

4. The possibilities and limitations for responsible port developments, in view of the Great Garuda Plan, were explained in section 4.1.3.

\subsection{Recommendations}

We analysed and evaluated Jakarta's Tanjung Priok port operations and plans on the basis of Responsible Innovation (RI) (see Tables 1 and 2), which enables the following recommendations (see Table 3 ):

1. Be inclusive: involve all stakeholders.

2. Be responsive: consider all stakeholder problems.

3. Be anticipatory: apply Impact Assessment, especially for the Great Garuda Plan after 2030.

4. Be reflective: apply the ESPO criteria in the Master Plan, especially those regarding societal integration, such as:

a. General public support and image

b. Education, labour market and (future) employees

c. Port-city relationships, around port areas, co-operate between cities and ports.

5. Balance conflicting values: analyse and identify value conflicts between health and environment (air pollution), safety (flood) and economics (port extension); create dialogue on values of stakeholders between Parliament, NGOs and fishermen. We strong recommend the use of non-optimising design methods, especially Satisficing, as explained in section 4.2.2 (see Table 4).

\section{References}

[1] Thao, N.D., Takagi, H. \& Esteban, M., Economic Growth and Climate Change Challenges to Vietnamese Ports. Coastal Disasters and Climate Change in Vietnam: Engineering and Planning Perspectives, eds. Thao, N.D., Takagi H. \& Esteban M., Elsevier: Oxford, pp. 339-354, 2014.

[2] Van den Hoven, J., Klaus, J., Nielsen, L., Roure, F., Rudze, L. \& Stilgoe, J., Options for Strengthening Responsible Research and Innovation, European Union: Luxembourg, 2013.

[3] Owen, P.R., Responsible Research and Innovation: Options For Research and Innovation Policy in the EU, University of Exeter Business School: United Kingdom, 2012.

[4] Stilgoe, J., Owen, R. \& Macnaghten, P., Developing a framework for responsible innovation. Research Policy, 42, pp. 1568-1580, 2013.

[5] Owen, R., Stilgoe, J., Macnaghten, P., Gorman, M., Fisher, E. \& Guston, D., A Framework for Responsible Innovation (Chapter 2). Responsible Innovation: Managing the Responsible Emergence of Science and 
Innovation in Society, eds. Owen, R., Bessant, J. \& Heintz, M., John Wiley \& Sons: Chichester, pp. 27-50, 2013.

[6] Van der Lei, T.E. \& Ligtvoet, A., Value Focused Thinking: An Approach To Structure Company Values For Asset Risk Management. WCEAM 2012: Proceedings of 7th World Congress on Engineering Asset Management, Daejeon, Korea, 8-10 October 2012.

[7] Van de Poel, I., Values in Engineering Design. Philosophy of Technology and Engineering Sciences, ed. A. Meijers, Elsevier: Amsterdam, pp. 9731006, 2009.

[8] Sundqvist, E., Backlund, F. \& Chronéer, D., What is Project Efficiency and Effectiveness? Procedia - Social and Behavioral Sciences, 119, pp. 278287, 2014.

[9] Van de Poel, I. \& Royakkers, L., Ethics, Technology and Engineering: An Introduction, Wiley-Blackwell: Chichester, 2011.

[10] Friedman, B., Kahn, J.P.H. \& Borning, A., Value Sensitive Design: Theory and Methods, Dept. Of Computer Science \& Engineering, University of Washington, 2002.

[11] Indonesia Population, http://worldpopulationreview.com/countries/ indonesia-population/

[12] World Bank: Indonesia World's 10th Largest Economy, http://thejakartaglobe.beritasatu.com/news/world-bank-indonesia-worlds10th-largest-economy/

[13] The Coordinating Ministry for Economic Affairs, Indonesia, Master Plan National Capital Integrated Coastal Development, Jakarta, 2014.

[14] Ravesteijn, W. \& Kop, J. (eds.), For Profit and Prosperity: The Contribution made by Dutch Engineers to Public Works in Indonesia 18002000, Aprilis: Zaltbommel and KITLV Press: Leiden, 2008.

[15] Port of Jakarta/Port of Tanjung Priok Expansion, Indonesia, http://www.ship-technology.com/projects/-port-jakarta-tanjung-priokexpansion/

[16] Aghamiri, M., Surez, W., Schoof, W., Kurniawan, V. \& Priyambodho, A., Proposal for a Cost-benefit Analysis of the Expansion of Tanjung Priok (Port of Jakarta), Master student report, TU Delft, 2014.

[17] King, M., Congestion at Tanjung Priok Dampens Indonesia's Economic Growth, http:/www.joc.com/economy-watch/world-economy-news/ congestion-tanjung-priok-dampens-indonesia $\% \mathrm{E} 2 \% 80 \% 99$ s-economicgrowth 20130206.html

[18] Oktania, I., Sustainable Harbour Development, MSc thesis, UNESCO-IHE: Delft, 2013.

[19] Ravesteijn, W., He, J. \& Chen, C., Responsible innovation and stakeholder management in infrastructures: The Nansha Port Railway Project. Ocean \& Coastal Management, 100, pp. 1-9, 2014.

[20] Grunwald, A., Technology Assessment: Concepts and Methods. Philosophy of Technology and Engineering Sciences, ed. A. Meijers, Elsevier: Amsterdam, pp. 1103-1146, 2009. 